\title{
The Taqwacores
}

\author{
Michael Muhammad Knight \\ Brooklyn: Soft Skull Press, 2004. 254 pages.
}

Novels are ideal vehicles for learning and teaching about the situation of modern Islam. The narrative form facilitates the reader's understanding that the pressing questions of contemporary religion are ones faced by human actors in their individual day-to-day lives and cannot (and should not) be generalized to all believers in a given faith everywhere. My own favorite in many years of teaching Islam in the context of an introductory course on "western" religions has been Cheikh Hamidou Kane's Ambiguous Adventure (originally published in French [1962; English translation 1963]), which broaches all of the fundamental tensions of modernity in the African and French contexts. But that book is now distant in time and cultural space, especially for young North American audiences, and stands only, I fear, as a historical portrait of the debate. Kane's work remains helpful in understanding how matters got to where they are today, but perhaps less so for engaging its readers in cultural debates immediately relevant to their lives.

Michael Muhammad Knight's The Taqwacores has gained an underground (and increasingly "above-ground" - it has been made into a film) reputation as a book engaged in the debate about the emergence of an "American" Islam. The first major literary effort by a convert to Islam, initially printed at Kinko's and flogged by the author at places like the ISNA annual meeting, it is a mirror of American youth culture of the twenty-first century tangling with the various manifestations of Islam - Sufism, Salafism, Shi ism, and the Nation of Islam among others - and finding its own particular way.

The novel follows a group of young men and women who, in a variety of cultural ways, identify themselves as Muslim. Their communal life in Buffalo is charted as the narrator, Yusef, falls under the influence of Jehangir, whose devotion to Californian punk music with a Muslim theme (taqwacore - a fictional category that has now become a reality) reaches its climax (a word I choose consciously here) in a concert at which all of the greatest bands perform as a result of Jehangir's initiative.

On the surface the work is excessively juvenile and extremely offensive. It is a manifestation of youthful male sexual fantasy (of a type that may be thought best kept as private thoughts) laced with language I prefer that my mother, wife, and daughter did not know that I knew. Its graphic description 
of constant attempts at male sexual "conquest" of women (and not infrequently, although noticeably less graphically, of other men) and the aimlessness of attending a university or working at menial jobs might be thought as of hardly providing an encouraging view of how young Muslims are finding their way in the world today. The story is basically one of the potential of youth wasted on music, drugs, alcohol, and sexual frustration.

So what, you may well ask, made this such a compelling read for me unless it is my own puritanical fascination and nostalgia for my own lost youth (factors I would not want to discount)? What has made this a work that apparently is a part of assigned reading in university courses on American Islam (much to my personal disbelief - as a university administrator, I would never advise that this book be assigned as course reading, certainly not by someone untenured)?

Contained within the novel is one of the most compelling discussions I have ever read of how Islam is to be lived in the modern world. Permeated by all the surface aspects of the practice of Islam (knowledge of devotional Arabic words and phrases as well as the standard Muslim books and names of intellectual heroes of the past is essential to understanding the book fully), the discussion of the form that being Muslim in America could and should take today is attacked head-on with a frankness that makes the issues come alive. All the issues are real ones that face all young people who wish to identify themselves as both Muslim and American (or Canadian or...). Every tough issue comes up in one way or another, both those of polemical concern (among them Muhammad's marriage to the child A'isha and the difficult Qur'anic passages regarding women, which one of the book's female characters has simply blacked out in her mushaf) and those that revolve around the extent to which the law must be followed or whether the heart and meaning of Islam resides in its (Sufi) spirituality. Some interesting discussions of the Sunni (Salafi) attitude toward Shi ism and its history also come up, especially in coming to an understanding of the meaning of Husayn as a model for tortured youth.

After reading The Taqwacores and talking a bit about it, some colleagues suggested that I might also be interested in the author's later Blue-Eyed Devil: A Road Odyssey through Islamic America (Brooklyn: Soft Skull Press, 2006). This is certainly a work that should be read in conjunction with (but after) the earlier book. It is a first-person account of the author of The Taqwacores (it is narrated as autobiography) in his cross-country search for Islam. The work is decidedly more mature and complex in its exploration of the different forms of Islam found in America today (especially in the search for the truth 
about the Nation of Islam), while still permeated by the same themes and attitudes of The Taqwacores. It contains some reflections upon the narrator's earlier fictional efforts (described, in an ironical voice, as that "dirty novel"), captured in the reaction of a "Sweet Hijabi Girl" who suggested that "all I had done was throw rotten eggs at the black velvet Kaaba cloth. That was cool in its way, but I would have liked it to mean more." (p. 15).

But can meaning ever emerge from such works, as Knight hopes? That such books utterly destroy an image of Muslims as unable to question their faith, bound as it is by an explicit and unchanging shari ah, is a certain outcome. Knight does not present answers to what "American Islam" must look like, but he knows that "Saudi Islam" is different from "Pakistani Islam" and different again from "African Islam," and thus there is no reason why something distinctive should not emerge. The function of a novel such as this (and it is a long tradition, as any reading of the Marquis de Sade, for example, will illustrate) is truly to shake things up, to question everything, and to open up discussion. The idiom in which it is done in The Taqwacores, while perhaps reflective of urban American youth today, will be found offensive by many, if not most, readers; but the reader's reflection upon its meaning afterward may make it worth the disturbing journey.

Andrew Rippin

Dean, Faculty of Humanities University of Victoria, British Columbia, Canada 